\title{
Information Sources and Perceived Success in Corporate Finance
}

\author{
Isto Huvila Department of the ALM, Uppsala University
}

This is a preprint of an article accepted for publication in Journal of the American Society for Information Science and Technology Copyright (C) 2010 (American Society for Information Science and Technology). This preprint has been updated to reflect changes in the final version. Abstract:

The work of corporate finance professionals is information intensive. In spite of that the practices and motivations of their information preferences have been researched very little. The present study investigates perceived success and how it is related to corporate finance professionals' information source use behaviour based on a web survey of 92 Finnish corporate finance professionals. The principal finding of the statistical analysis of the data is that perceptions of work success and specific types of information sources contributing to the success are related. The correlations are complex and very different types of information sources contribute to individual types of success and vice versa. The findings indicate that information sources function as measures of success and serve an instrumental purpose. Besides functional relations, the correlation of the variables suggest more comprehensive success and information source use related dependencies and preferences. The findings imply that by studying existing perceptions of success it is possible to make inferences about preferred information sources. The study also suggests that both personal and organisational perceptions of success should to be taken into account when planning information services and information literacy education for corporate finance professionals in order to increase their effectiveness and relevance for the professionals.

\section{Introduction}

The productivity and effectiveness of information and knowledge use in business contexts has long been an important issue (Davenport \& Prusak, 1997; Kirk, 1999). Some of the major areas of research on this matter are knowledge management (Davenport \& Prusak, 1997), intellectual and social capital (Stewart, 1997; Nahapiet \& Ghoshal, 1998), information culture (Ginman, 1993; Widén-Wulff, 2000), communities of practice (Wenger, 1998), knowledge sharing (Widén-Wulff \& Ginman, 2004; Widén-Wulff \& Davenport, 2005; Widén-Wulff, 2007) and knowledge engineering (Studer, Benjamins, \& Fensel, 1998). Much of the emphasis has been placed on knowledge management technologies, even though the necessity of focusing on nontechnical infrastructures, conventions and practices has been stressed for years (Davenport \& Prusak, 1997; Wenger, 1998; Widén-Wulff \& Ginman, 2004). It seems that only rather recently have these aspirations gained ground in practical discourse (Capozzi, 2007). However, for both practitioners (Capozzi, 2007) and researchers alike, the focus of the human oriented concerns has been in managing externalised formal information, turning tacit knowledge into explicit, or managing people and groups with critical internalised expertise (Davenport \& Prusak, 1997; Tan, 
Plowman, \& Hancock, 2007). In contrast, the equally critical aspects of explicating the human aspects of information, the strategic potential of information and informedness in finance and business contexts (McGee, Prusak, \& Pyburn, 1993; Amaro de Matos, 2001; Bebczuk, 2003; Hall, 2006; Tirole, 2006) has been a relatively rare viewpoint even though its significance was underlined a long time ago (McGee, Prusak, \& Pyburn, 1993).

The present study focuses on one aspect of information and its strategic importance, namely the perceived potential of information to contribute to the success of work in corporate finance context. This study addresses the issue of why some information sources are selected and used, and some others not, and why the chosen sources are not always the most apparently relevant ones. The question is how information source preferences are related to perceived measures of success of work. The findings are based on a web survey of $(\mathrm{N}=) 92$ Finnish professionals working on corporate finance related duties in different organisations. The respondents were asked to indicate how important 21 different measures of success of work were for themselves. Further, the respondents were asked to indicate how important various types of information sources (46 alternatives) were for them in being successful in their work. Based on these findings, the present study discusses how information source preferences (what information sources are seen as important to success) and measures of success of work are related.

\section{Literature review}

\section{Information sources and information behaviour in business contexts}

Information source is a carrier of information that makes it shareable. Documents, situations and places can all be sources of information (Byström, 2002). Information related human behaviour or information behaviour has been defined by Wilson as "the totality of human behavior in relation to sources and channels of information, including both active and passive information seeking, and information use" (Wilson, 2000, p. 49). Like information seeking behaviour or information searching behaviour (Wilson, 2000), the information source behaviour (or information source preferences) discussed in the present study can be seen as a part of the broader phenomenon of information behaviour. Patterns of information behaviour have been explicated in the literature using models (e.g. Ellis, 1993; Leckie \& Pettigrew, 1997; Wilson, 1999) and metaphoric concepts such as Solomon's (1997) information mosaics and Chatman's (1999) theory of life in the round.

In spite of the acknowledged impact of informedness in corporate finance, there is little empirical research on the specifics of the information behaviour of corporate finance and business professionals. Besides the lack of research, another complicating factor is the breadth of the notion 'corporate finance' (“A Dictionary of Finance and Banking”, 2008). In practice, for many, corporate finance is the business of a large group of people with other related duties as well (e.g. Megginson, Smart, \& Lucey, 2008). Therefore, the present study assumes an 
exploratory approach and an inclusive view of both corporate finance and corporate finance related information. As working definitions, corporate finance professionals are considered to be people who work with corporate financing related duties either fulltime or part-time, and corporate finance information is assumed to be any general, business, economics and more specifically corporate finance related information that is capable of informing and is relevant in corporate finance duties.

Information and informedness have been studied in economics as factors explaining market activity and market behaviour (e.g. Akerlof, 1970; Shah, 1994; Davis, 2006; Tirole, 2006). These studies do not, however, address the subtleties of being informed or not, or relate to the actual information behaviour of business or more specifically corporate finance professionals. Most of the existing information science research on business and corporate finance professionals' information behaviour is based on the experiences of corporate librarians and information specialists. Rennie and Kershaw (1994) have investigated the views of corporate information specialists on professionals' information use in mergers and acquisitions. Business Information Review has published reviews of major financial and business information sources (e.g. Mowat, 1986; Freeman, 1992; A. Foster \& Foster, 2002; P. Foster \& Foster, 2006; A. Foster, 2009a). The major groups of sources mentioned in different reviews tend to be official publications, various reference sources (mostly directories), statistics, newsletters, (professional) journals, databases, and organisations. Research in various forms and various corporate finance and business related organisations are also mentioned frequently as sources of information. The mixture of content, form and channels as information sources underlines that, in practice, users seldom make clear distinctions between these analytical notions (e.g. Sonnenwald, Wildemuth, \& Harmon, 2001; Savolainen \& Kari, 2004; Peterson, Aslani, \& Williams, 2003). Therefore, even the present study has assumed an inclusive notion of information source as anything users perceive as capable of informing.

Instead of surveying the views of information specialists, Broady-Preston and Hayward (2001) studied information processing and information needs in the UK financial services sector by interviewing strategic management of the UK retail banks. The managers interviewed in the study acknowledged the significance and relevance of accurate, current, quality information as a critical input into strategy formulation. Leonidou et al. studied the export information behaviour of small firms (Leonidou \& Adams-Florou, 1999; Leonidou \& Theodosiou, 2004). Anderson (1988) published a comparative analysis of information search and evaluation behaviour of professional and non-professional financial analysts concluding that the both groups for the most part use the same information sources although their significance is weighted differently. Besides the in-depth studies, there are also some surveys on information source use. A major change in information source behaviour since the 1990s has been the advent of web based information services. As early as 2000 Harris Interactive reported that banking and brokerage customers were fast moving away from printed information to web services (Harris Interactive, 2000).

Today, information sources are increasingly put on users' desktops. According to Foster (2009a), younger business information users in particular prefer desktop access. Many professionals have become keen to select, mix and process their own data instead of resorting to 
published sources of information. At the same time the demand for easily digestible reports has increased among investors (Asquith, Mikhail, \& Au, 2005), managers and decision makers (Jewell, 2002). Managers prioritise issue specific information sources and especially specific commissioned reports over general publicly available information sources (Broady-Preston \& Hayward, 2001). The apparent complexities of information source preferences suggest that general factors of information behaviour such as personality (Heinström, 2006; Hyldegård, 2009), personal preferences, and work tasks (Byström \& Hansen, 2005) may be of interest in the context of the present study.

The principal channels of accessing finance and business information are the information services provided by the major international information service vendors. Traditionally there has been a difference between market data and general business information vendors, but at the moment the major players are providing the both (Ainsworth, 2009). Bloomberg and Thomson Reuters are the two major players in real time data (A. Foster, 2009b). The top four vendors of general business information in the UK libraries in 2009 were Lexis-Nexis, Thomson Reuters, BvD and Factiva. Even though the major players are only a few, businesses tend to subscribe to a median of eight vendors (A. Foster, 2009a).

Although the market and aggregate data providers are few, there are plenty of other frequently used information sources. Professional journals serve as a source of specific and general opinions and provide a general overview of the business environment (McKinsey \& Company, 2004a). Financial announcements are frequently used to make judgements about companies (Guay \& Harford, 2000). Holland and Johanson (2003) found that analysts use a wide variety of information sources to assess corporate tangibles and intangibles. Also, as Broady-Preston and Hayward (2001) found, it is often difficult to identify the exact piece of information, which led to a decision. Experts seldom know why they know (Bouwman, Frishkoff, \& Frishkoff, 1987).

The usability of information depends on many factors. Users tend to value quality, currency and speed of delivery, but also comprehensiveness and presentation of information. The latter two are valued less by information professionals (Rennie \& Kershaw, 1994). It has been suggested that financial indicators such as capital structure are used as means to communicate the quality and future prospects of companies, but according to Kwan (1996), this is rarely the case. Also Saville (2004) noted that formal indicators and, for instance, accounting data are not necessarily as useful as might be assumed. The earlier observations of Anderson (1988) are in line with these findings. It is more often informal criteria, such as financial flexibility, credit ratings, earnings per share dilution, and recent stock price appreciation, that are the most important factors affecting policy decisions (Graham \& Harvey, 2001). The lasting role of informal information sharing is also underlined by the findings confirming the greater significance of private information rather than public information in various financial decisions (Brown \& Hartzell, 2001). Social information sources in particular require a high degree of reciprocity in information exchange in order to be judged as useful (Holland \& Johanson, 2003). According to Garciá (2005), analysts tend not to use the information on tangibles communicated by companies in presentations. In many cases the most useful information is highly informal as Saxenian (1996) found out in a study of informal information exchange between professionals in 
Silicon Valley area. Informal sources such as discussions with top management, site visits and interviews with expert and market players appear in business consulting materials (e.g. McKinsey \& Company, 2004a,b,c)

\section{Perceived success}

Work success has been an object of considerable interest especially in terms of career success, gender differences (e.g. Orser \& Dyke, 2005) and success perceptions in the small business context (Hudson, Smart, \& Bourne, 2001). As Heslin (2005) remarked, however, there has been relatively little research on the nature of career success as a complex phenomenon that entails both self-referent and social criteria. The same observation seems to apply to work success in general. Basic dichotomies between objective and subjective (Heslin, 2003) internal and external (Porac, Nottenburg, \& Eggert, 1981) and between economic and non-monetary success dimensions have been used as a baseline (Cooper \& Artz, 1995). The problem with typical objective measures (pay, promotions) is that they are dependent on a number of external factors and may not represent actual success to individuals. Subjective measures are biased by their assumptions on the organisation of work and that people compare their achievement primarily to their personal goals instead of how others perform (Heslin, 2003).

In spite of their problematic nature, the most commonly used objective measures of success are salary and promotions (Heslin, 2003). There is greater variation in subjective measures. The Greenhaus et al. career satisfaction scale has been used and discussed in several studies (Heslin, 2003; Judge, Heller, \& Mount, 2002; Boudreau, Boswell, \& Judge, 2001). Peluchette and Jeanquart (2000) and Walker and Brown (2004) have presented other scales based on subjective measures.

The most commonly identified factors of success perceptions are gender, personality, education, mentoring relationships, and career tactics (Heslin, 2003). Sturges (1999) identified internal (accomplishment, achievement, enjoyment, integrity, balance, personal recognition and influence) and external (grade and reward) criteria of success in a qualitative study of 18 male and 18 female managers from the UK. Parker and Chusmir (1992) studied six success measures among 439 female and 317 male managers and non-managers. Personal fulfilment and security were reported to be more important to female managers than males. In the group of nonmanagers, women rated family relations and personal fulfilment higher than males, but scored lower on status/wealth. Fenwick and Hutton (2000) found that women perceive success more broadly than simply in terms of business success (profit, size and growth). Their informants mentioned children, personal sense of satisfaction, reputation and, explicitly, the secondary importance of money. The Justo, De Castro, Coduras, \& Cruz (2006) study presents similar findings.

Considering the general notion of work success, the research conducted in small and medium sized enterprises is of special interest for the present study, because in these cases organisational goals are not separate from the personal preferences of the entrepreneurs (Walker \& Brown, 2004). Hudson, Smart, \& Bourne (2001) have studied the topic from the business performance 
point of view and have classified critical dimensions of performance to quality, time, flexibility finance, customer satisfaction and human resources.

Orser and Dyke (2005) studied the perceptions of success of Canadian business owners and corporate managers using respectively 18 and 24 item scales assuming a similarly broad definition of success as Walker and Brown (2004) and Hudson, Smart, \& Bourne (2001). The corporate survey employed success criteria related to employment flexibility, working with competent people, supportive workplace culture, financial security, and opportunities to participate in community activities. The small business owner survey used questions related to company profitability, product or service quality, market acceptance, and operating performance.

\section{Method}

The aim of this study was to find patterns between perceived success at work and the information sources perceived to contribute to this success. In order to control the effect of contextual variables the population was limited to professionals working with corporate finance related duties. The data were collected using a survey questionnaire. The survey was conducted online using Lime Survey 1.0 open source survey software. The data were analysed using correlation (rcorr and cor.test) and regression analyses (a stepwise GLM using $1 \mathrm{~m}$ and add1) on R 2.8.1.

The measures of perceived success were tested using a 21 item questionnaire on a five point Likert scale. Respondents were asked to indicate how they perceived the importance of the measures of success listed in the Table 2 ("Following factors indicate that I have been successful in my work"). The measures were based on the perceived success measures used by Orser and Dyke (2005) using the scales of Peluchette and Jeanquart (2000) and Walker and Brown (2004) as references.

\section{Insert table 1 here}

The perceived importance of various information sources for the success of their work was measured using a 46 item questionnaire on a five point Likert scale (Table 1, the options were clarified by examples) with an open question asking for other relevant information sources not included in the survey. Answers to the open question confirmed the importance of a number of included sources, but did not reveal any new ones. Respondents were asked to indicate how important they considered information sources to be for the success of their work. The categories of information sources were based on earlier studies of information source behaviour (Huvila, 2006 ) with a specific focus on the literature on information behaviour in corporate finance and economics discussed earlier in this article (principally Broady-Preston \& Hayward, 2001; Holland \& Johanson, 2003; A. Foster, 2009a). The choice of particular information sources was based on those mentioned as important or informative in the literature on corporate finance and business information. Similarly, the notion of information source was perceived as inclusive of anything informants in earlier studies had considered informative without making analytical 
distinctions between information sources, media or channels. The approach was motivated by earlier experiences that non-specialist information users tend to have an inclusive view of information sources and it is not uncommon to consider a channel such as Internet (e.g. Peterson, Aslani, \& Williams, 2003) or a search engine as a source of information. For instance, the studies of Sonnenwald, Wildemuth and Harmon (2001), and Savolainen and Kari (2004) show that informants seldom make the distinction. The list was complemented with general information sources identified from earlier information behaviour literature. The resulting set of information sources was revised and individual sources and examples were reformulated after a discussion with a corporate finance professional with experience both as a practitioner and a researcher in the field of corporate finance.

\section{Respondents}

A convenience sample $(\mathrm{N}=92)$ of employees working with corporate finance issues in Finnish companies was recruited to participate in a web survey. The respondents were recruited by sending e-mail invitations to professionals listed in Fonecta ProFinder B2B database (Fonecta, accessed Nov 16, 2007). The invitations were sent between October 2007 and February 2008. Professionals with financial management and corporate finance related titles were chosen from the database. The professionals were asked in the invitation to participate in the survey if their work duties involved (corporate) finance related duties. The approach was chosen in order to reach a broader variety of people working with corporate finance related duties in different organisations than only those who are fulltime corporate finance professionals. There is a documented difference in the information behaviour of employees in larger and smaller companies (e.g. Broady-Preston \& Hayward, 2001; Graham \& Harvey, 2001). Full-time corporate finance officers tend to be employed only by larger companies and financial institutions while finance is managed in smaller companies on a part time basis (Työ- ja elinkeinoministeriö, 2008a).

65 out of $92(71 \%)$ of the respondents were men and $27(29 \%)$ women. 60 out of $89(67 \%)$ respondents had a master's degree. Their mean age was 43.78 years (sd 9.54, median 42, range 26-62). Respondents were confident about their skilfulness (self-evaluated competence mean 4.06 , sd .70, median 4.00 on a five point scale) and represented a variety of organisations with between 7 and over 28000 employees and with revenues between $€ 1.5$ million and $€ 6.4$ billion. 27 out of $92(29 \%)$ respondents worked in financial institutions (banks, insurance companies, financial service providers) and $65(71 \%)$ represented other industries.

In 20083982 out of 250378 (1.6\%) Finnish companies were categorised as financial institutions according to Statistics Finland. The mean revenue of all Finnish companies was 1.4 million Euros (Statistikcentralen, 2008). Financial institutions and large companies are thus overrepresented in the sample. A large number of especially smaller companies do not have specific corporate finance functions or employees, because their financing is based on cash flow and direct bank loans (Hietala, 2008). Large companies and especially financial institutions, on 
the other hand, always or almost always employ corporate finance professionals (Työ- ja elinkeinoministeriö, 2008b). The finance sector employs 40000 people in Finland of which banks employ 24000, insurance companies 13000 and other organisations 3000 (Työ- ja elinkeinoministeriö, 2008a). In summary, there is an unknown bias in the sample that has to be taken into account when interpreting the results.

\section{Analysis}

\section{Success and information sources}

Correlation analysis (rcorr) of the perceived importance of information sources for the success of the respondents' work and measures of success was used to identify patterns of correlation between the two groups of variables. Stepwise general linear models (GLM) (lm, add1) were used to compare measures of success and information sources.

\section{Insert table 2 here}

The links between success measures and information sources were visualised using a network diagram drawn using Pajek (Batagelj \& Mrvar, 1996-) with Kamada-Kawai algorithm (Kamada \& Kawai, 1989).

\section{Insert Figure 1 here}

The clustering of both the information sources and success measures was tested using factor analysis (factanal, varimax-rotation) with 3-6 factors. The analyses revealed no significant correlation patterns between the groups and individual variables.

\section{Information sources and background variables}

Correlation analysis (rcorr) of the indicators of success and background variables was used to identify patterns of correlation between the two groups of variables. Stepwise general linear models (GLM) (lm, add1) were used to compare success variables and the respondents' selfperceived work proficiency (1-5), work experience (years), work duties, age, gender and the turnover of the employing company.

\section{Insert table 3 here}




\section{Discussion}

The present study confirms earlier findings on the complexity and multi-dimensionality of the information behaviour of finance professionals (e.g. Broady-Preston \& Hayward, 2001; Graham \& Harvey, 2001; Holland \& Johanson, 2003). Information is sought from a variety of sources and the purposes vary between individuals. The role of informal information sharing is common and as the present findings suggest, it is considered to be contributing to the success of work (Saxenian, 1996; Brown \& Hartzell, 2001; Holland \& Johanson, 2003). Unlike Foster (2009a), the present study could not find a correlation between the age of the respondents and preference for web based information. Similarly, no correlation between gender and success measures was found (cf. Parker \& Chusmir, 1992; Heslin, 2003; Fenwick \& Hutton, 2000; Justo, De Castro, Coduras, \& Cruz, 2006).

Success measures partly followed the patterns shown in the literature. Career and personality related variables, (Heslin, 2003) work experience and self-perceived proficiency, correlated most often to the different perceptions of success. Unlike in earlier studies, gender seemed to be an insignificant determinant of success perceptions (Fenwick \& Hutton, 2000; Heslin, 2003; Justo, De Castro, Coduras, \& Cruz, 2006). Similarly, the findings may indicate that the gender specific preferences can in some cases be more stereotypical rather than actual. However, it is also possible that the sample is biased in this respect. Findings seem to suggest further that perceived success is closely related to an orientation towards success. Individuals who consider themselves successful, appreciate qualitative long-term measures of success such as quality, long-term goals, personal conviction and organisational efficiency. Work experience, on the other hand, seems to relate to quantifiable and measurable success factors such as profits, personal efficiency, customer feedback and operational goals.

In terms of the correlation of information source preferences and success perceptions, information sources are related to specific types of perceiving success in work. The findings show that the self-perceived importance and preference of specific information sources to the success of work is related to how the corporate finance professionals perceive whether they have been successful in their work. For instance, commissioned analysts' reports and market information are considered to be helpful when success is measured by the profits of organisation. Similarly, statistics in general and financial statistics in particular, contribute to being successful in terms of short-term organisational success (Table 2).

The correlations between background variables and success measures are listed in Table 3 . Self-perceived competence and work experience were the most common variables associated with different perceptions of success. Self-perceived competence compensates for the use of financial statistics in the case of S_SHORTTERM (for abbreviations, see Table 2) and work experience for the use of statistics and consultation of information specialists in the case perceiving success in the light of customer feedback (S_CUSTFEDBCK). In general, however, information sources add to the other variables strengthening the argument that information sources are indeed perceived to be contributing to success.

The co-occurrence of the same information sources together with different success measures 
suggests that the same or similar information sources can be used in different contexts to serve different functions. Conferences are an example of the versatility of information sources. Conferences contribute to personal performance (S_OWNPERF), they increase the effectiveness of one's own work (S_OWNEFF), help to gain influence (S_INFLUENCE) and function as a source of feedback from colleagues (S_COLFEEDBCK). The associated co-occuring success measures may suggest that conferences can be an efficient source of information (from a personal point of view), but also a more informal channel of advocacy and feedback. As in the study of Saxenian (1996), they represent occasions when boundaries between organisations are lowered for the mutual benefit of participating individuals and institutions.

The preference for professional journals relates to the quality of work (S_QUALITY) and efficiency of the organisation (S_EFFICIENCY) and to the amount of personal influence (S_INFLUENCE) and efficiency (S_OWNEFF) of one's own work. Journals can be interpreted as containing easily digestible quality information (from the organisation's point of view) in such a form that is easy to use in setting up goals for one's own work and advocating them within the organisation. Professional journals are also a likely source of such information that fits well with the generally accepted contemporary measures of quality and efficiency.

Statistics show a similar pattern of being related to four success measures. Success measured on the short-term success of the organisation (S_SHORTTERM) is related to both financial statistics and statistics in general. Long-term success (S_LONGTERM) of an organisation is also related to statistics, but not to the financial statistics. Besides organisational success, statistics are related to organisation efficiency (S_EFFICIENCY) and customer feedback (S_CUSTFEEDBACK). It is possible that the respondents are using (various types of) statistical information to learn how to attain organisational success in the short and long term. Simultaneously, it seems that statistics are an efficient source of information, because they contribute to the increased efficiency of work. The relation of statistics and customer feedback can be interpreted to suggest both the importance of statistical customer feedback and statistics as an important source of information in user preferences.

Personal contacts relate to three different success measures: one's own work performance (S_OWNPERF), personal confidence in one's own success (S_OWNCONV) and the quality of the work (S_QUALITY). Contacts may be conceived to serve as efficient sources of information (from the personal performance point of view), but also as a channel for getting feedback on personal performance. The use of information specialists relates to success measured by happiness (S_HAPPY), customer feedback (S_CUSTFEEDBCK) and reaching operational goals (S_OPERGOALS). A possible interpretation is that information specialists are capable of providing easy to use information (in the sense of keeping users happy) that is relevant to the broad perspectives of operational goals and customer preferences.

The result that information sources can be related to rather different kinds of success measures suggests that they serve different functions for different users and contexts. The fact that factor analysis did not reveal correlations between clusters of information sources and success measures, and individual variables, strengthens this impression. In several instances, it seems that an information source is used as a measure or feedback that is discussed as a pertinent 
element of processual information behaviour models (Wilson, 1999). Sources such as conferences, chatting with colleagues, browsing the web or brochures, provide a way to acquire feedback from colleagues, superiors, clients and partners and the general public (S_COLLFEEDBCK, S_SUPFEEDBCK, S_EXTFEDBCK, S_PUBLFEEDBCK). On the other hand, information sources are used instrumentally to achieve desired types of success. This resembles the instrumental relationship of information behaviour and work tasks described by Byström and Hansen (2005). Courses are related to learning (S_LEARN), and professional journals and conferences are fora for advocating personal influence, as face validity logics would predict. In a similarly instrumental manner, information specialists can provide an effective way out of information problems and thus can contribute to the joy of work.

Besides being used as measures and instruments, the correlations of some information sources and success factors seem to be personality related rather than directly functional. The observation resonates with the earlier findings that both perceptions of success (Heslin, 2003) and information behaviour are related to personal factors (Heinström, 2006). According to the present study, browsing contributes to success measured by how well private life and work is combined. Similarly a personal conviction of success (S_OWNCONV) and self-reflection as an information source are related. Instead of indicating a de facto source of information, this correlation might be taken as an indication of an attitude. A broad and comprehensive view of useful information sources might indicate a similarly comprehensive view of a personal lifeworld. In a similar fashion, the success measured by the feedback from superiors correlates to using colleagues as an information source and subscribing to RSS-feeds or email alerts of new reports and other information. This is not really an indication that talking to colleagues and subscribing to information sources directly affects the feedback. Rather it could be interpreted as an indication of anxiety to be informed about what is going on and what close, important or respected people think at the moment.

The pattern is repeated in the co-occurrence of success measures together with information source types. Reconciliation of work and private life (S_PRIVLIFE) is related to browsing, web based financial news services, courses and memos. One's own performance (S_OWNPERF) is related to announcements of forthcoming publications, personal information and conferences. A possible interpretation for the two groups of information sources is that they are efficient and convenient when it comes to the use of time and amount of new information acquired. Long-term success of an organisation (S_LONGTERM) is related to statistics, and general and financial news sources on the web that all are capable of providing information on the current general financial climate.

Holland and Johanson (2003) discuss how analysts develop a mosaic-like picture of a company or sector they work with using various kinds of information sources. Solomon (1999) uses the same metaphor of evolving patterns of information behaviour in three different contexts. In the present study, the mosaic-like view of information is exemplified by the diversity of information sources perceived to be important, how individual sources and combinations are linked to distinct contexts, needs (as in Guay \& Harford, 2000; McKinsey \& Company, 2004c) and types of success. In many cases, the types of success are related to a combination of very 
different sources with informal sources appearing together with more formal ones suggesting the types of diversity reported, for instance, by Bouwman(1987), Broady-Preston and Hayward (2001), Graham and Harvey (2001) and Saville (2004). In spite of the market share and prominence of market information and financial news providers (A. Foster, 2009b), these sources are significantly correlated only to a few measures of success. Both formal information and access to personal discussions with management, experts and employees play a significant role. The significance of private and personal information noted in several earlier studies (Saxenian, 1996; Brown \& Hartzell, 2001; Holland \& Johanson, 2003; McKinsey \& Company, 2004a,b,c; Garciá, 2005) is especially evident with more qualitative forms of success. The complexity of the information source and success network shown in the present study and especially the pattern of how information sources tend to have both resource and measuring functions can be seen as an indication of this kind of complexity. Another expression of the complexity is the simultaneous preference of raw data and easily digestible reports observed by Asquith, Mikhail and Au (2005). In this respect, the findings of the present study indicate that data is preferred when success is measured in calculable terms while reports, news and journals are preferred with qualitative terms of success.

On the level of preference and perceived importance of individual information sources, the present findings resemble those of earlier studies. In comparison to the earlier studies which focused primarily on formal published information sources (e.g. P. Foster \& Foster, 2006; A. Foster, 2009a), the most significant difference is the pronounced role of personal aspects of information source behaviour and social information sources in the present study. The dominance of the web is both apparent and hidden in the results of the present study. Most of the information sources associated with success such as market information, statistics or news are accessible on web services on the users' desktops (Harris Interactive, 2000; A. Foster, 2009a), but the web as such seems to have limited perceived value as a source of information. In an analytical sense the web is primarily a channel, not a source.

The factor analysis did not result in definite clustering of the sources, but the network graph (Fig. ??) gives some grounds to suggest that two larger groups might exist. The first one (on the right) collects quality, influence and efficiency related success measures and primarily personal and professional information sources while the other cluster on the left consists of published information and diverse personal, feedback related and organisational measures of success. Future studies might be able to provide deeper insights into these provisional groups.

\section{Conclusions}

The principal finding of this study is that perceptions of work success and specific types of information sources contributing to the success are related. The correlations are complex and very different types of information sources contribute to individual types of success and vice versa. Information sources function as measures of success and serve an instrumental purpose. In addition to functional relations, the correlation of the variables suggests more comprehensive 
success and information source use related dependencies and preferences.

The findings suggest that both personal and organisational perceptions of success are relevant when planning information services and information literacy training for corporate finance professionals. The instrumental value of information sources is related to personal measures of success as well as to external criteria of preference such as work duties. If the perceptions of success were taken into account, it might be possible to provide professionals with more meaningful information from their personal point of view. It could however, affect how the professionals work and perceive success by recommending and guiding them to use particular information sources that are related to more pertinent measures of success from the point of view of the employing organisation. If a particular information source appears to be used as a measure of (from the organisational point of view) of a less relevant type of success, provision of another type of information source could be considered. The findings also imply that by studying existing perceptions of success it is possible to make inferences about preferred information sources. For reference services, information management and information literacy training in organisations, the practical implication of the findings is that it is relevant to acknowledge the existence and possible effects of the varying perceptions of success when planning information services. On the other hand, information might be considered as a steering measure to affect the ways that how success is perceived. It is, however, clear that more research is needed for more detailed recommendations and to understand the relation of information source preferences and perceptions of success in more detail.

\section{References}

Ainsworth, M. (2009). Market data and business information: Two peas in a pod? Business Information Review, 26(2), 81-89.

Akerlof, G. (1970). The market for 'lemons': quality uncertainty and the market mechanism. Quarterly Journal of Economics, 84(3), 488-500.

Amaro de Matos, J. (2001). Theoretical Foundations of Corporate Finance. Princeton University Press Princeton.

Anderson, M. J. (1988). A comparative analysis of information search and evaluation behavior of professional and non-professional financial analysts. Accounting, Organizations and Society, 13(5), 431-446.

Asquith, P., Mikhail, M. B., \& Au, A. S. (2005). Information content of equity analyst reports. Journal of Financial Economics, 75(2), 245-282.

Batagelj, V., \& Mrvar, A. (1996-). Pajek - program for large network analysis. Retrieved May 14, 2010, from http://pajek.imfm.si/doku.php

Bebczuk, R. (2003). Asymmetric Information in Financial Markets: Introduction and Applications. Cambridge University Press.

Boudreau, J., Boswell, W., \& Judge, T. (2001). Effects of Personality on Executive Career Success in the United States and Europe. Journal of Vocational Behavior, 58, 53-81.

Bouwman, M. J., Frishkoff, P. A., \& Frishkoff, P. (1987). How do financial analysts make decisions? a process model of the investment screening decision. Accounting,

Organizations and Society, 12(1), 1-29. 
Broady-Preston, J., \& Hayward, T. (2001). Strategy, information processing and scorecard models in the uk financial services sector. Information Research, 7(1), paper 1. Retrieved May 14, 2010, from http://InformationR.net/ir/7-1/paper122.html

Brown, G. W., \& Hartzell, J. C. (2001). Market reaction to public information: The atypical case of the Boston Celtics. Journal of Financial Economics, 60(2-3), 333-370.

Byström, K. (2002). Information and information sources in tasks of varying complexity. Journal of the American Society for Information Science and Technology, 53(7), 581-591.

Byström, K., \& Hansen, P. (2005). Conceptual framework for tasks in information studies. Journal of the American Society for Information Science and Technology, 56(10), 10501061.

Capozzi, M. M. (2007, June). Knowledge management architectures beyond technology. First Monday, 12(6). Retrieved May 14, 2010, from http://www.firstmonday.org/issues/issue12_6/capozzi/

Chatman, E. (1999). A theory of life in the round. Journal of the American Society for Information Science, 50(3), 207-217.

Cooper, A. C., \& Artz, K. W. (1995). Determinants of satisfaction for entrepreneurs. Journal of Business Venturing, 10(6), 439 - 457.

Corporate finance (2008). In J. Law \& J. Smullen (Eds.), A dictionary of finance and banking. Oxford Reference Online. Oxford: Oxford University Press.

Davenport, T. H., \& Prusak, L. (1997). Working knowledge: How organizations manage what they know. Boston, MA, USA: Harvard Business School Press.

Davis, A. (2006). Media effects and the question of the rational audience: lessons from the financial markets. Media, Culture \& Society, 28(4), 603-625.

Ellis, D. (1993). Modeling the information-seeking patterns of academic researchers. Library Quarterly, 63(4), 469-486.

Fenwick, T., \& Hutton, S. (2000). Women crafting new work: The learning of women entrepreneurs. In 2000 AERC proceedings. Retrieved May 14, 2010, from http://www.edst.educ.ubc.ca/aerc/2000/fenwickthuttons1-web.htm

Fonecta. (2009). Profinder B2B. Retrieved May 14, 2009, from http://profinderb2b.fonecta.com

Foster, A. (2009a). Battening down the hatches: The Business Information Survey 2009. Business Information Review, 26(1), 10-27.

Foster, A. (2009b). Initiatives-June 2009: A round up of products and initiatives. Business Information Review, 26(2), 135.

Foster, A., \& Foster, P. (2002). Business information in the end-user age: Business Information Resources Survey, 2002. Business Information Review, 19(1), 5-22.

Foster, P., \& Foster, A. (2006). Stability is not immobility: Business Information Resources Survey 2006. Business Information Review, 23(2), 83-107.

Freeman, O. (1992). Banking and financial services: the major information sources. Business Information Review, 9(2), 2-25.

Garciá, E. (2005). Bridging the gap between disclosure and use of intellectual capital information. Journal of Intellectual Capital, 6(3), 427-440.

Ginman, M. (1993).Why do companies need a positive information culture?. In M. Ginman (Ed.), Information culture and business performance, p. 1-9. Åbo: Institutionen för biblioteksvetenskap och informatik, Åbo Akademi.

Graham, J. R., \& Harvey, C. R. (2001). The theory and practice of corporate finance: evidence from the field. Journal of Financial Economics, 60(2-3), 187-243.

Guay, W., \& Harford, J. (2000, September). The cash-flow permanence and information content of dividend increases versus repurchases. Journal of Financial Economics, 57(3), 385-415. 
Hall, M. (2006). Knowledge management and the limits of knowledge codification. Journal of Knowledge Management, 10(3), 117-126.

Harris Interactive. (2000). Internet study reveals more banking and brokerage customers turning to the web for key financial information (Press release). Retrieved May 14, 2010, from http://www.harrisinteractive.com/news/index.asp?NewsID=149\&HI_election=Harris Interactive

Heinström, J. (2006). Broad exploration or precise specificity: Two basic information seeking patterns among students. Journal of the American Society for Information Science and Technology, 57(11), 1440-1450.

Heslin, P. (2003). Self- and Other-Referent Criteria of Career Success. Journal of Career Assessment, 11(3), 262-286.

Heslin, P. (2005). Conceptualizing and evaluating career success. Journal of Organizational Behavior, 26(2), 113-136.

Hietala, H. (2008). Pk-yritysten suhdannenäkemys, lokakuu 2008. Suomen Yrittäjät. Retrieved May 14, 2010, from http://www.yrittajat.fi/File/aafefc1d-423c-4101-868f2027358f6d94/Pk_yritysten_suhdannetila2008.pdf

Holland, J., \& Johanson, U. (2003). Value-relevant information on corporate intangibles creation, use, and barriers in capital markets - between a rock and a hard place. Journal of Intellectual Capital, 4(4), 465-486.

Hudson, M., Smart, A., \& Bourne, M. (2001). Theory and practice in SME performance measurement systems. International Journal of Operations and Production Management, 21(8), 1096-1115.

Huvila, I. (2006). The ecology of information work - a case study of bridging archaeological work and virtual reality based knowledge organisation. Åbo: Åbo Akademi University Press. (Diss. Åbo Akademi University)

Hyldegård, J. (2009). Personality traits and group-based information behaviour: an exploratory study. Information reseach, 14(2). Retrieved May 14, 2010, from http://informationr.net/ir/14-2/paper402.html

Jewell, M. (2002). Information services in investment banking: their evolution and future. Business Information Review, 19(3), 23-29.

Judge, T., Heller, D., \& Mount, M. (2002). Five-factor model of personality and job satisfaction: A meta-analysis. Journal of Applied Psychology, 87(3), 530-541.

Justo, R., De Castro, J. O., Coduras, A., \& Cruz, C. (2006). Entrepreneurs' Perceptions of Success: Examining Differences Across Gender and Family Status [Working Paper Series]. SSRN eLibrary. Retrieved May 14, 2010, from http://papers.ssrn.com/sol3/papers.cfm?abstract_id=1019259

Kamada, T., \& Kawai, S. (1989). An algorithm for drawing general undirected graphs. Information Processing Letters, 31(1), 7-15.

Kirk, J. (1999, February). Information in organisations: directions for information management. Information Research, 4(3). Retrieved May 14, 2010, from http://informationr.net/ir/43/paper57.html

Kwan, S. H. (1996, January). Firm-specific information and the correlation between individual stocks and bonds. Journal of Financial Economics, 40(1), 63-80.

Leckie, G. J., \& Pettigrew, K. E. (1997). A general model of the information seeking of professionals: role theory through the back door? In ISIC '96: Proceedings of an international conference on information seeking in context (pp. 99-110). London, UK: Taylor Graham Publishing.

Leonidou, L. C., \& Adams-Florou, A. S. (1999). Types and sources of export information: 
Insights from small business. International Small Business Journal, 17(3), 30-48.

Leonidou, L. C., \& Theodosiou, M. (2004). The export marketing information system: An integration of the extant knowledge. Journal of World Business, 39(1), 12-36.

McGee, J., Prusak, L., \& Pyburn, P. (1993). Managing Information Strategically: Increase Your Company's Competitiveness and Efficiency by Using Information as a Strategic Tool. John Wiley and Sons.

McKinsey \& Company. (2004a). Decision to invest in British manufacturing (Case Study).

McKinsey \& Company. (2004b). Expansion into Eastern Europe (Case Study).

McKinsey \& Company. (2004c). Improving the low market valuation of a company (Case Study).

Megginson, W. L., Smart, S. B., \& Lucey, B. M. (2008). Introduction to corporate finance. London: Cengage Learning EMEA.

Mowat, M. (1986). Information sources in Accountancy and Finance. Business Information Review, 3(2), 3-9.

Nahapiet, J., \& Ghoshal, S. (1998). Social capital, intellectual capital, and the organizational advantage. Academy of Management Review, 23(2), 242-266.

Orser, B., \& Dyke, L. (2005). Gender differences in perceived success among business owners and corporate managers. In Conference Proceedings from the International Council for Small Business, Washington, june 15-18.

Parker, B., \& Chusmir, L. H. (1992). A comparison of men and women managers' and nonmanagers' perceptions of success. Human Resource Development Quarterly, 3(1), 7384.

Peluchette, J. V., \& Jeanquart, S. (2000). Professionals' use of different mentor sources at various career stages: implications for career success. J Soc Psychol, 140(5), 549-564.

Peterson, G., Aslani, P., \& Williams, K. A. (2003). How do consumers search for and appraise information on medicines on the internet? a qualitative study using focus groups. $J \mathrm{Med}$ Internet Res, 5(4), e33.

Porac, J. F., Nottenburg, G., \& Eggert, J. (1981). On extending Weiner's attributional model to organizational contexts. Journal of Applied Psychology, 66(1), 124-126.

Rennie, J., \& Kershaw, C. (1994). Corporate mergers \& acquisitions: the role of the information department. Business Information Review, 10(4), 31-59.

Saville, A. (2004). Improving the usefulness of accounting data in financial analysis. South African Journal of Economic and Management Sciences, 7(3), 504-520.

Savolainen, R., \& Kari, J. (2004). Placing the internet in information source horizons. a study of information seeking by internet users in the context of self-development. Library \& Information Science Research, 26(4), 415-433.

Saxenian, A. (1996). The boundaryless career: a new employment principle for a new organizational era. In D. M. R. Michael Bernard Arthur (Ed.), (pp. 23-39). New York: Oxford University Press.

Shah, K. (1994). The nature of information conveyed by pure capital structure changes. Journal of Financial Economics, 36(1), 89-126.

Solomon, P. (1997). Discovering information behavior in sense making. I. Time and timing. Journal of the American Society for Information Science, 48(12), 1097-1108.

Solomon, P. (1999). Exploring the contexts of information behaviour. In T. Wilson \& D. K. Allen (Eds.), (p. 150-175). London: Taylor Graham.

Sonnenwald, D. H., Wildemuth, B. M., \& Harmon, G. L. (2001). A research method using the concept of information horizons: An example from a study of lower socio-economic students' information seeking behaviour. The New Review of Information Behaviour, 2, $65-$ 86. 
Statistikcentralen. (2008). Statistisk årsbok för Finland (eng. statistical yearbook for Finland) (Vol. 103). Helsingfors.

Stewart, T. (1997). Intellectual capital: the new wealth of organizations. Doubleday New York, NY, USA.

Studer, R., Benjamins, V. R., \& Fensel, D. (1998). Knowledge engineering: Principles and methods. Data Knowledge Engineering, 25(1-2), 161-197.

Sturges, J. (1999). What it means to succeed: personal conceptions of career success held by male and female managers at different ages. British Journal of Management, 10(3), 239252.

Tan, H. P., Plowman, D., \& Hancock, P. (2007). Intellectual capital and financial returns of companies. Journal of Intellectual Capital, 8(1), 76-95.

Tirole, J. (2006). The theory of corporate finance. Princeton University Press.

Työ- ja elinkeinoministeriö. (2008a). Pankki-, vakuutus- ja rahoituspalveluala. Retrieved May 14, 2010, from http://www.ammattinetti.fi/pankki-vakuutus-ja-rahoituspalveluala

Työ- ja elinkeinoministeriö. (2008b). Rahoitusasiantuntija. Retrieved May 14, 2010, from http://www.ammattinetti.fi/rahoitusasiantuntija

Walker, E., \& Brown, A. (2004). What Success Factors are Important to Small Business Owners? International Small Business Journal, 22(6), 577-594.

Wenger, E. (1998). Communities of Practice: Learning, Meaning, and Identity. Cambridge: Cambridge University Press.

Widén-Wulff, G. (2000). Business information culture: a qualitative study of the information culture in the Finnish insurance industry. Information Research, 5(3). Retrieved May 14, 2010, from http://informationr.net/ir/5-3/paper77.html

Widén-Wulff, G. (2007). Challenges of knowledge sharing in practise: A social approach. Oxford: Chandos.

Widén-Wulff, G., \& Davenport, E. (2005). Information sharing and timing: findings in two Finnish organizations. In F. Crestani \& I. Ruthven (Eds.), Information Context: Nature, Impact, and Role: 5th International Conference on Conceptions of Library and Information Sciences, CoLIS 2005, Glasgow, UK, June 4-8, 2005 (Vol. 3507, p. 32-46). Heidenberg: Springer-Verlag.

Widén-Wulff, G., \& Ginman, M. (2004). Explaining knowledge sharing in organizations through the dimensions of social capital. Journal of Information Science, 30(5), 448-458.

Wilson, T. (1999). Models in information behaviour research. Journal of Documentation, 55(3), 249-270.

Wilson, T. (2000). Human Information Behavior. Informing Science, 3(2), 49-55.

\section{Figure Captions}

\section{List of Figures}

Figure 1. Connections between success measures and information sources. Drawn using Pajek with Kamada-Kawai algorithm. 